\title{
Pilomatricoma in a Case of Xeroderma Pigmentosum
}

\author{
Kaoutar Laamari*, Hanane Baybay, Samia Mrabat, Zakia Douhi, Sara Elloudi and Fatima Zahra \\ Mernissi \\ Department of Dermatology, University Hospital Hassan II, Morocco
}

*Corresponding author: Kaoutar Laamari, Department of Dermatology, University Hospital Hassan II, Morocco

\begin{tabular}{|c|c|}
\hline ARTICLE INFO & Abstract \\
\hline Received: 幽 April 29, 2020 & \multirow{2}{*}{$\begin{array}{l}\text { Citation: Kaoutar L, Hanane B, Samia M, Zakia D, Sara E, Fatima Zahra M. Pilomatrico- } \\
\text { ma in a Case of Xeroderma Pigmentosum. Biomed J Sci \& Tech Res 27(4)-2020. BJSTR. } \\
\text { MS.ID.004540. }\end{array}$} \\
\hline Published: May 15, 2020 & \\
\hline
\end{tabular}

\section{Clinical Image}

Xeroderma pigmentosum (XP) is a genodermatosis characterized by pigmentary abnormalities, solar skin damage and cutaneous malignancies in the sun-exposed areas. The various skin tumors seen in XP include basal and squamous cell carcinomas, malignant melanomas and less commonly keratoacanthomas, angiomas, fibromas and sarcomas. Pilomatricoma is a benign neoplasm with differentiation towards the hair matrix and has been reported in a single case in association with XP [1]. We report

a new case for such an occurrence. A 9-year-old boy, a known case of familial XP presented with one nodular lesion, on the nose measuring $1 \mathrm{~cm}$ of four months duration (Figure 1). It was an erythematous, rounded nodule, firm in consistency and showed no overlying skin changes. In the dermoscopic view, we can find irregular white structures, some reddish homogeneous areas. There was no lymphadenopathy. This lesion was excised and sent for histopathological study and the diagnosis of pilomatricoma was made (Figure 2).

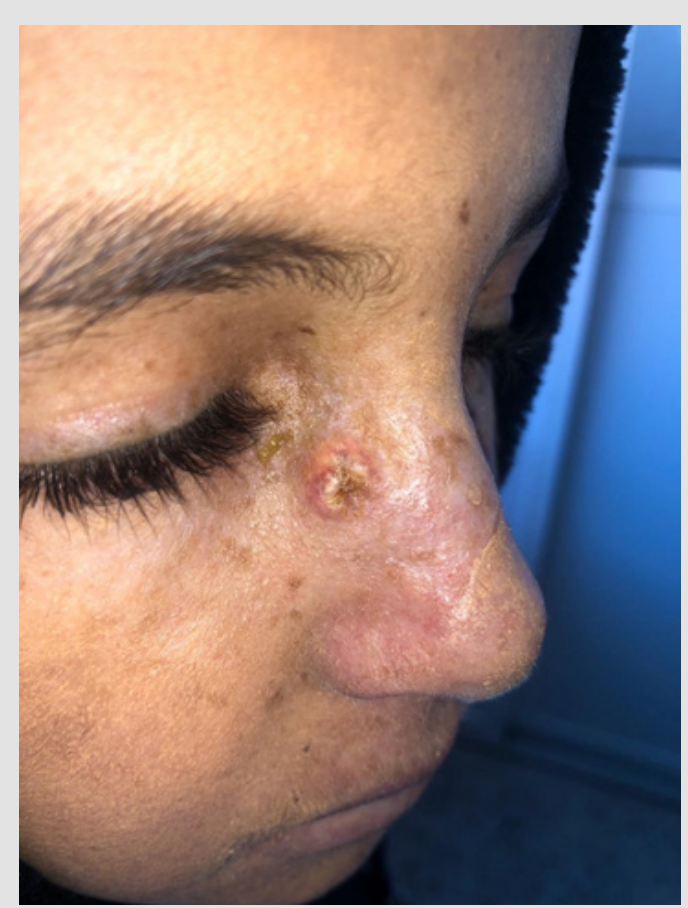

Figure 1: An erythematous, rounded nodule, firm in consistency and showed no overlying skin changes. 


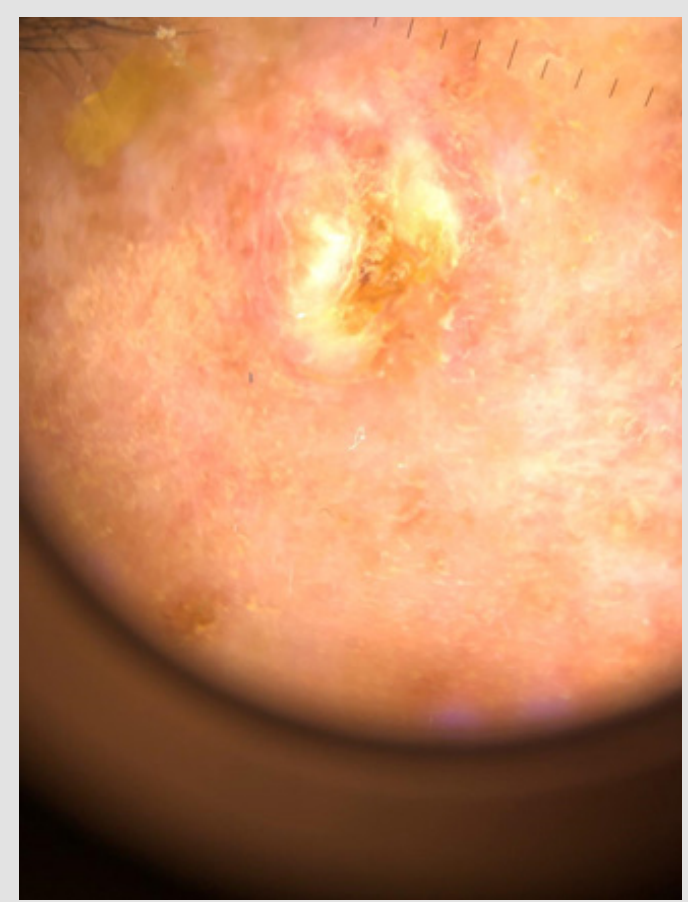

Figure 1: In the dermoscopic view, we can find irregular white structures, some reddish homogeneous areas.

\section{References}

1. Robbins JH, Kraemer KH, Lutzner MA, Festoff BW, Coon HG (1974) Xeroderma pigmentosum. An inherited disease with sun sensitivity, multiple cutaneous neoplasms and abnormal DNA repair. Ann Intern Med 80(2): 221-248.

ISSN: 2574-1241

DOI: $10.26717 /$ BJSTR.2020.27.004540

Kaoutar Laamari. Biomed J Sci \& Tech Res

(C) This work is licensed under Creative

Submission Link: https://biomedres.us/submit-manuscript.php

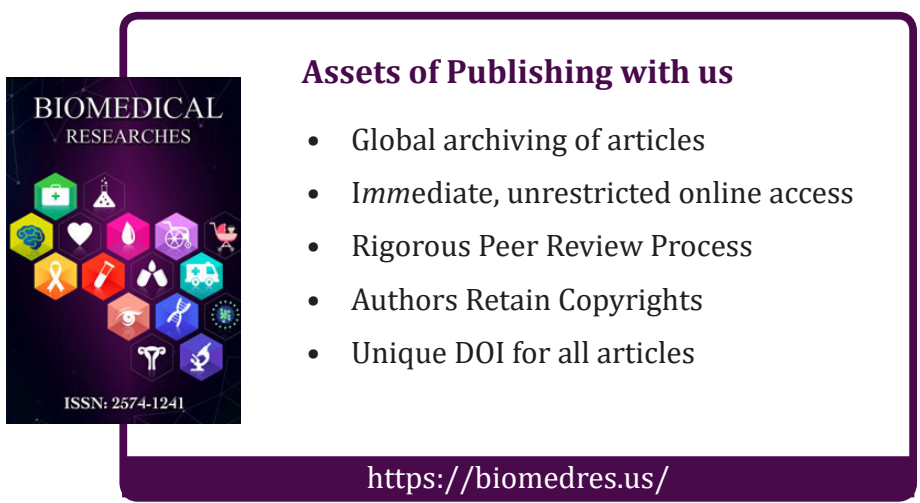

